\author{
R C Linton, M D, F W Walker, MD, AND \\ W E SPOEREL, M D, F R C P (C) *
}

\title{
INTRODUCIION
}

INTERMITTENT POSITIVE PRESSURE BREATHING has been widely accepted for the management of respiratory fallure, and many excellent reports have dealt with problems of pulmonary ventilation and the clinical results of this method 1-9 Between January 1, 1960, and Decembel 31, 1964, 201 cases of respuratory insufficiency were treated with the Burd respirator at Victoria Hospital in London, Ontario In the following discussion, we intend to describe the types of patients given respirator care during this five-year period and present our assessment of the results of respirator care and the problems with infection, and our observations regarding the management of hopeless cases

The indication we considered for the use of intermittent positive pressure breathing was inadequate pulmonary ventilation as determined by clinical evaluation of the patient, by spurometry employing the Wright respirometer, and by analysis of arterial blood gases These same methods were used to assess the efficiency of treatment once it was begun However, in a number of cases a catastrophe such as cardiac or respiratory arrest brought the senousness of the respiratory problem to the fore and respiratior treatment was only instituted after acute resuscitation

\section{Presentation of Cases}

For the purpose of description the cases have been divided into the following five main groups based on the functional pathology

\section{Central Respiratory Depression}

In 60 patients the respiratory insufficiency was the result of central respuratory depression caused by drug intoxication, cerebral trauma or infection, status epilepticus, or post-anoxic depression following cardiac arrest (Table $\mathbb{I} a$ )

\section{Spmal Cord land Neuro-Muscular Problems}

Twenty-two patients suffered from paralysis of respiratory muscles The Guillan-Barré syndrome and neuromuscular insufficiency associated with muscle relaxants comprised the majority of these cases Myasthenia, tetanus, spinal cord injury, and a group of other neuropathes made up the remainder (Table $\mathbf{I} b$ )

Department of Anaesthesia, University of Western Ontario and Victoria Hospital, London, Ontario Presented at the Canadian Anaesthetss $\mid \mathbf{s}^{\prime}$ Society Meeting, Charloltetown, PEI, June 23, 1965 


\begin{tabular}{|c|c|c|c|c|}
\hline & & $\begin{array}{l}\text { No of } \\
\text { cases }\end{array}$ & Died & Survived \\
\hline$a$ & $\begin{array}{l}\text { Central Respuatory Depression } \\
\text { Drug intoxication } \\
\text { Brain trauma } \\
\text { Brain infection } \\
\text { Status epilepticus } \\
\text { Post-cardiac arrest }\end{array}$ & $\begin{array}{r}10 \\
29 \\
6 \\
2 \\
13\end{array}$ & $\begin{array}{r}1 \\
27 \\
4 \\
0 \\
11\end{array}$ & $\begin{array}{l}9 \\
2 \\
2 \\
2 \\
2\end{array}$ \\
\hline$b$ & $\begin{array}{l}\text { Spinal Cord and Neuro-Muscular Problen } \\
\text { Guillain-Barre syndrome } \\
\text { Other neuropathies } \\
\text { Muscle relaxant } \\
\text { Tetanus } \\
\text { Spinal cord injury } \\
\text { Muscular dystrophy and myasthenia }\end{array}$ & $\begin{array}{l}8 \\
4 \\
6 \\
1 \\
1 \\
2\end{array}$ & $\begin{array}{l}1 \\
2 \\
1 \\
0 \\
1 \\
0\end{array}$ & $\begin{array}{l}7 \\
2 \\
5 \\
1 \\
0 \\
2\end{array}$ \\
\hline$c$ & $\begin{array}{l}\text { Skeleto-Muscular Problems } \\
\text { Crushed chest } \\
\text { Post-thoracotomy } \\
\text { Post-abdominal } \\
\text { Chest deformity }\end{array}$ & $\begin{array}{r}20 \\
21 \\
17 \\
1\end{array}$ & $\begin{array}{r}7 \\
12 \\
13 \\
1\end{array}$ & $\begin{array}{r}13 \\
9 \\
4 \\
0\end{array}$ \\
\hline$d$ & $\begin{array}{l}\text { Pulmonary Parenchymal Problems } \\
\text { Post-cardio-pulmonary bypass } \\
\text { Pneumonia } \\
\text { Diffusion defect } \\
\text { Respiratory distress sy ndrome }\end{array}$ & $\begin{array}{r}18 \\
10 \\
13 \\
4\end{array}$ & $\begin{array}{r}12 \\
8 \\
9 \\
4\end{array}$ & $\begin{array}{l}6 \\
2 \\
4 \\
0\end{array}$ \\
\hline
\end{tabular}

\section{Skeleto-Muscular Problems}

Skeleto-muscular disorders gave rise to iespiratory insufficiency in 59 patients Twenty patients with a crushed chest required positive pressure ventilation Inadequate respiration after thoracic or abdominal surgery was the reason for therapy in the other 39 patients ( Table $\mathbb{I} c$ )

\section{Pulmonary Parenchymal Problems}

Eighteen patients were ventilated following cardio-pulmonary bypass Advanced widespread pneumonia was the indication for respirator treatment in ten patients, while thirteen were treated for a variety of conditions associated with diffusion defects such as Hamman-Rich syndiome, pulmonary fibrosis, or pulmonary oedema Four newborns with respiratory distress syndrome were treated without success ( Table Id)

\section{Emphysema}

Fifteen cases of decompensated emphysema were treated, and eight survived

\section{Discussion}

Table II presents a summary of our 201 patient;, showng the average length of respiratory treatment as well as survival rates It should be noted that, in these five groups, the survival rate appeared to be drectly related to the duration of respirator treatment It would be fallacious to draw any conclusion from this mathematical relationship, however, and it is not possible to come to any cuitical 
assessment of the efficiency of total respirator care on the basis of the above data or similar classifications based on diagnostic groupings ${ }^{1-9}$ or physiological considerations ${ }^{10}$

TABLE II

\begin{tabular}{|c|c|c|c|c|c|}
\hline Clinical condition & $\begin{array}{c}\text { Total no. } \\
\text { of cases }\end{array}$ & Died & Survived & $\begin{array}{l}\text { Average } \\
\text { duration of } \\
\text { therapy } \\
\text { (days) }\end{array}$ & $\begin{array}{c}\text { Survival } \\
(\%)\end{array}$ \\
\hline Central respiratory depression & 60 & 43 & 17 & 48 & 28 \\
\hline Spinal cord and neuro-muscular problem & ms 22 & 5 & 17 & 319 & 77 \\
\hline Skeleto-muscular problems & 59 & 33 & 26 & 77 & 44 \\
\hline Pulmonary parenchymal problems & 45 & 33 & 12 & 38 & 27 \\
\hline Emphysema & 15 & 7 & 8 & 93 & 53 \\
\hline
\end{tabular}

In evaluating the efficacy of respirator treatment based on survival and subsequent well-being, the prognosis of the underlying disease giving rise to the respiratory insufficiency must be considered For this reason a selection was made of all patients in whom the underlying disease had a favourable prognosis, providing the respuratory fallure was effectively treated

In Table III, conditions with a potentially favourable prognosis have been listed, these patients should all have survived with efficient respirator care The 46 patients classufied here had a mortality rate of only 18 per cent However, sux of the eight deaths were due to the development of a pulmonary infection while the patient was on the respirator

TABLE III

Potentially Favourable Prognosis

\begin{tabular}{lrcc}
\hline \multicolumn{1}{c}{ Problem } & Number & Survived & Died \\
\hline Drug intoxication & 10 & 9 & 1 \\
Status epilepticus & 2 & 2 & 0 \\
Guillain-Barre syndiome & 8 & 7 & 1 \\
Muscle relaxants & 6 & 5 & 1 \\
Tetanus & 1 & 1 & 0 \\
Spinal cord injury & 1 & 0 & 1 \\
Myasthenia & 2 & 2 & 0 \\
Uncomplicated crushed chest & 12 & 10 & 2 \\
Other neuropathies & 4 & 2 & 2 \\
Total & -16 & 38 & 8 \\
\hline
\end{tabular}

Survival rate, $82 \%$

This "respirator lung," as we termed the infection colloquially, usually began with bronchospasm and a decreasing compliance Bronchodulators and higher inflation pressures improved ventalation at first but later became less and less effective The chest film showed widespread bronchopneumonia Finally pulmonary ventilation became impossible, very high inflation pressures could not force enough oxygen into the lungs to mant the lungs had the consistency of liver, the alveol being completely filled with inflammatory exudate 
This type of pathology was definitely responsible for the unsuccessful outcome of the respirator treatment in the six cases mentioned above Similar pulmonary infections were observed in many other cases and may have been occasionally responsible for the death Some patients survived the condition after treatment with massive doses of antibiotics, cortisone, and adrenalin of the organisms cultured from the bronchı in these cases, pseudomonas, coagulase positive staphylococci, $E$ coli, and proteus were common in our respirator cases Little attention has been given to this problem in the literature ${ }^{11}$

To reduce the alarmingly frequent appearance of the "respirator lung" the following attempts were made to control possible source, of infections

1 Suction bottles and tubing were changed and sterllized three times every day Onlly autoclaved catheters were used for tracheal suction

2 Stagnant water in nebulizers and tubings was elıminated by frequent changes of all attachments to the Bud respirator and by the discontinuation of all "Q" crrcle attachments In the latter it was found that the condensing moisture contaned large numbers of bacteria

3 Nebulizers such as the Puritan and the Bird were sterilized before each use Pseudomonas could be cultured from nebulizers that had been washed only between treatments

4 As a further measure, disposable gloves were used routinely for every tracheal suction Our bacteriologist reported a colony count ten times higher in suction procedures with the washed bare hands as compared to unwashed hands covered with disposable gloves ${ }^{12}$

These changes, and particularly the routine use of disposable gloves, have been in full effect since November 1964 Although it would appear too early to assess fully the significance of these measures, no case of the "respurator lung" described above has been seen since that time However, pseudomonas and $E$ coll continue to be cultured, and crowded conditions make more effective controls impossible without interfering with the nursing care of the patient

In Table IV conditions are listed which have a potentially unfavourable prognosis Here only 17 per cent of the patients survived In the other 64 patients, treatment of the respiratory fallure was unsuccessful in influencing the fatal outcome of the underlyning disease Bram trauma and cerebral anoxia following

TABLE IV

Unfayourable Prognosis

\begin{tabular}{lccc}
\hline \multicolumn{1}{c}{ Problem } & Number & Survived & Died \\
\hline Head trauma & 29 & 2 & 27 \\
Cerebral anoxia (post-cardiac arrest) & 13 & 2 & 11 \\
Complicated crushed chest ${ }^{\text {Ek }}$ & 8 & 3 & 5 \\
Extensive pneumonia & 10 & 2 & 8 \\
Diffusion defects & 13 & 4 & 9 \\
Respiratory distress syndrome & 4 & 0 & 4 \\
Total & $\frac{4}{77}$ & -13 & 64 \\
\hline
\end{tabular}

Survival rate, $17 \%$

*Associated with injuries to the brain, abdominal crgans, or kidneys, or with multiple major fractures 
cardiac arrest of sufficient degree to cause respiratory depression or persistent apnoea were almost always hopeless, less than 10 per cent of these patients survived and this is in agreement with other reports ${ }^{5,7}$ Patients suffering from these disorders presented a rather characteristic picture of "decay" Comment on the developments will provide a useful guide to their management Having shown temporary signs of recovery with the improved ventilation, the patients regressed into a deeper state of coma as judged by the disappearance of reflex responses previously present (Fig 1) The pupls became nonreactive to light and dilated Then the blood pressure fell, vasopressor support of the circulation, usually begun at that time, gradually diminished in effectiveness, and increasing doses were required Subsequently the body temperature began to fall to subnormal levels The heart beat, as the last sign of life, usually became imperceptible when the body temperature had fallen to levels between $36^{\circ}$ and $32^{\circ} \mathrm{C}$ This sequence of events lasted anywhere from 24 to 96 hours and, depending on the circumstances of the case, was associated with a variety of concentrated and costly therapeutic attempts

Respiratory arrest in patients with cerebral damage due to trauma, following an anoxic episode, or in the course of a brain infection, had an extremely poor prognosis In such a patient who was well ventulated and oxygenated, a progressive fall in blood pressure was probably indicative of a fallure of the vasomotor centre $A$ fall in body temperature indicated a breakdown of the heatregulating mechanism Loss of cerebral function to this extent was not compatible with survival Experience has shown that treatment is futile at the stage of falling body temperature

In a last group of 78 patients a prognostrc assessment could not be made in view of the many factors involved Pre-existing pathology, co-existing disease, and surgical intervention with subsequent secondary complications and functional derangements of which respiratory insulficiency was only one aspect, made it difficult or impossible to evaluate the efficacy of respirator treatment Objective improvement of the condition was observed in almost all patients after commencement of respirator treatment The high mostality of 64 per cent in this group was largely determined by the multuple respuratory and non-respiratory problems Pulmonary infection was often present in the terminal stages of these patients Although in all cases the respirator care was necessary for survival, in some the pulmonary complications introduced by this treatment could not be excluded as contributing to the fatal outcome

Respirator care of patients in a general hospital has been possible without a specially designed respiratory unit Patients were looked after in an intensive care unit and in the recovery room, both in close proximity to the operating rooms Nuises in these locations were particularly familiar with respuratory problems and their care Such a location also provided a more readily avalable source of anaesthetists and other medical personnel to diagnose and manage aurway problems and other emergencies Standardization of equipnent was distunctly advantageous in that the use of one type of respirator fostered familiarify with the technical aspects of respurator care

The control of the pulmonary infections refenred to previously and the 


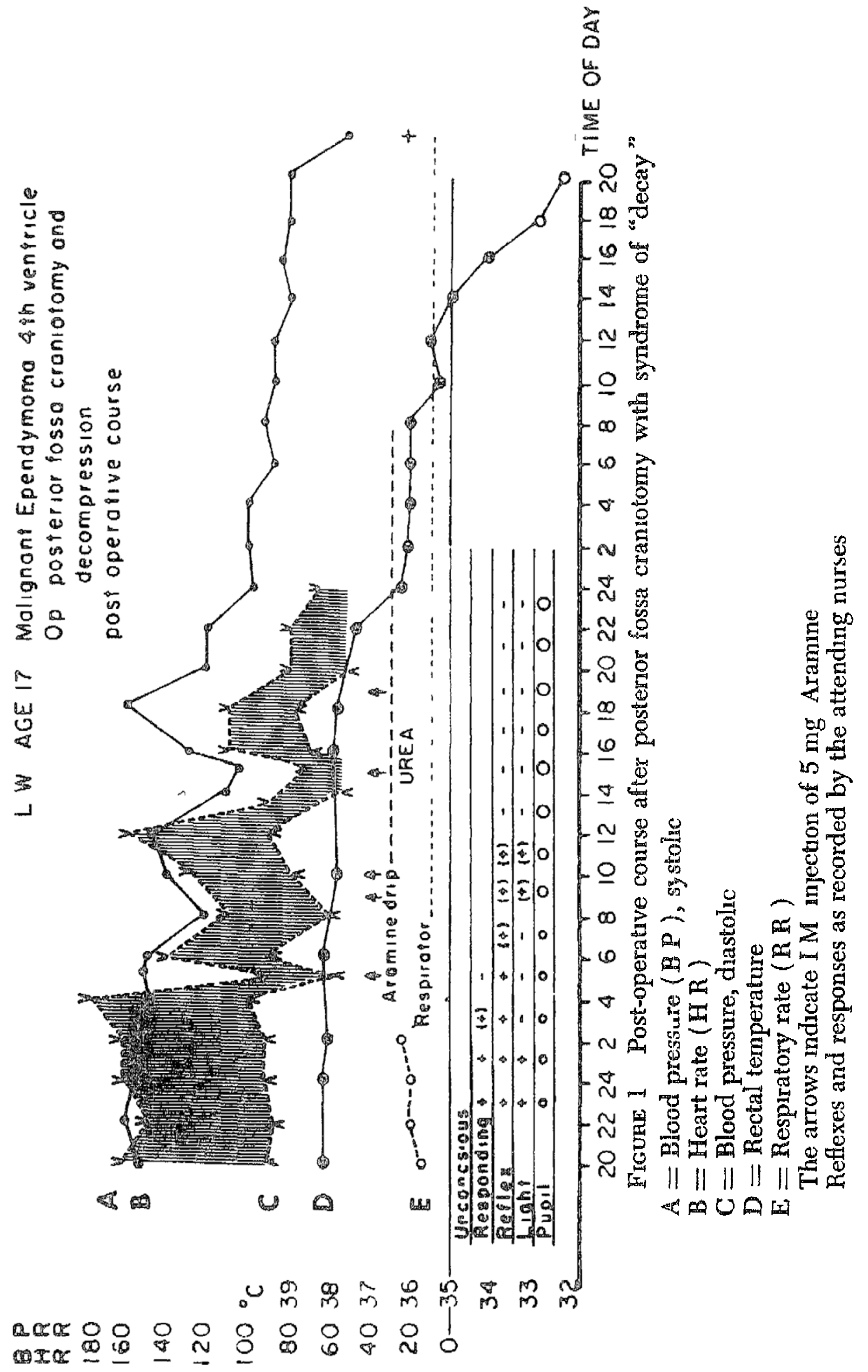


early recognition of respiratory insufficiency were major problems Diverse aspects in the control of pulmonary infection ranged from the design of rooms with adequate space to the design of respirators, from the management of patients to the education of nurses and attending medical staff Education also contributed to the development of a greater a wareness of respiratory insufficiency, resulting in a continuing increase in the use of intermittent positive pressure breathing during the past five years This inciease is reflected in the number of respirators required in the hospital there are now twelve, and there were originally two A still greater demand for respirator care is anticipated in the future

\section{SUMmary}

In a general hospital, 201 respirator cases have been managed by the Department of Anaesthesia Although the over-all survival rate was 40 per cent, a classification based on the prognosis of the condition that caused the respiratory insufficiency showed that an 82 per cent survival rate was obtained in patients with a potentially favourable prognosis Pulmonary infection was the main cause of death in this group, and measures to control contamination of the arrway appeared to improve the patient's chance of survival Patients with a potentially unfavourable prognosis had a very low survival rate (17 per cent) and the clinical observation of a terminal "decay syndrome" was of prognostic value

Patients in whom the respinatory insufficiency was only one of many other derangements usually benefited at least ternporarily from respirator treatment Although the high moitality rate in this group (64 per cent) was only in part associated with respirator care, it could be lowered by the prevention of pulmonary infection

It was thought that the control of infection and the prevention of contamination was a greater problem than the mantenance of adequate pulmonary vent1lation in determining the success of respirator care The avoidance of pulmonary infection together with the earlier 1 ecognition of respiratory insufficiency and the well-timed institution of respirator therapy could improve our results

\section{Resumé}

Dans un hôpital général, le Service d'anesthésie s'est occupé de 201 cas traités à l'arde de respirateurs Bien que le taux de survie en général n'art été que de 40 pour cent, une classification, basée sur le prognostıc de la maladıe qui avait causé l'insuffisance respiratoire, nous a démontré une survie de 82 pour cent chez les malades dont le prognostic était favorable $\mathrm{La}$ principale cause de la mort dans ce groupe a été l'infection pulmonarre, et ce qui a amélioré la survie, ce sont les mesures prises pour contrôler la contamination des voies ıespiratorres Les malades chez qui le prognostıc était moins bon ont conservé un taux de survie très bas (17\%), et l'observation clinıque d'un syndrome de chachexıe termınale nous a servi de valeui prognostique

Les malades chez qui l'msuffisance resprratorre n'étart qu'une pathologıe parmı 
plusieurs ont généralement bénéficié du traitement au respirateur, du moins temporairement Bien que le taux élevé de morlalité dans ce groupe (64\%) n'était associé qu'en partie aux soins d'un respirateur, Il serait possible de I améliorer par la prévention de l'infection pulmonaire

Nous avons la conviction que le contrôle de l'inlection et la prévention de la contamination nous ont posé de plus sérıeux problèmes que le maintien d'une ventulation pulmonarre adéquate pour évaluer le succès des soins au respirateur La prévention de l'infection pulmonarre aussı bien que le dépıstage plus précoce de l'insuffisance respiratorre et l'installation bien minutée de la thérapıe au respirateur pourraient améliorer nos résultats

\section{REFERENCES}

1 HoL vDAHL, M H The Respiratory Care Unit Anesthesiology 23559 (1962)

2 Woolf, $\mathbf{C} \mathbb{R}$ The Respiratory Unit at the Toronto General Hospital Canad M A J 84466 (1961)

3 Spalding, J M K \& Crampton-Smith, A Clinical Fractice and Physiology of Artificial Respiration Oxford Blackwell Publications (1963)

4 Robiie, D S \& Feldman, S A Expenence with Fifty Patients Treated with Artificial Ventilation Brit J Anaesth 35771 (1963)

5 Fairley, H B The Toronto General Hospital Respiratory Unit Anaesthesia 16267 (1961)

6 Fairley, H B \& Chambers, $R$ A The Management of the Patient with Respiratory Insufficiency Canad Anaesth Soc J 7447 (1960)

7 Mushin, W W The Assisted Respiration Unit Internalional Anesthesiology Clinics, $3152(1964)$

8 Pontoppidan, H Prolonged Artuficial Ventulation Postgrad Med 37576 (1965)

9 FAirley, $H$ B Respiratory Insufficiency International Anesthesiology Clinics $] 351$ (1963)

10 Fletcher, C M Definition and Classification of Ciuses of Respiratory Failure, Proc Roy Soc of Med 55565 (1962)

11 Gotsman, M S \& Whitby, J L Respuratory Infection following Tracheostomy Thorax 1989 (1964)

12 Campsall, E W R Personal communication 